\title{
Liquid Crystalline Flows Induced by Electric Field and Its Application
}

\author{
Kensaku ISHIMARU, Tomohiro TSUJI, Shigeomi CHONO
}

\begin{abstract}
We performed two kinds of fundamental experiments for developing liquid crystalline micro-actuators. The first experiment was to measure the velocity distribution of back-flow between parallel plates under an electric field. The gap of an experimental cell was $50 \mu \mathrm{m}$, and its twist angle was $0^{\circ}$. We obtained that the velocity distribution was antisymmetric with respect to the center plane of the cell. In addition, the magnitude of measured velocity was agreed well with numerical predictions. The second experiment was to try to move the upper plate, by the induced back-flow. Gap of the plates was $300 \mu \mathrm{m}$, and weight of the upper plate was about $0.05 \mathrm{~g}$. As a result, the upper plate was moved by $38 \mu \mathrm{m}$ with the maximum velocity of $179 \mu \mathrm{m} / \mathrm{s}$.
\end{abstract}

Keywords: Liquid crystal, Back-flow, Actuator

\section{1. 緒 言}

ネマティック液晶に電場を印加すると, 棒状の液晶分子は長軸 が電場方向に沿うように再配向する. 図1に示すように, 分子が 回転するとそこに速度公配少発生し，結果として液晶全体に流動 (背流)が誘起されるり. 図 2 は平行平板間に封入された液晶の 分子が電場に応答する様子と，そのとき発生する背流の速度分布 の模式図である. 同図は平板間の全ての液晶分子が平板に対して 平行に配向した状態を初期条件としたものであるが，背流の方向 と大きさは分子配向のねじれ角 (ツイスト角)や印加する電場に よってコントロール可能であることが数值計算により明らかに されている(2).しかし，背流の速度分布の実測はまだ行われてい ない，また，図2において上下の平板は固定されているため壁面 での速度は 0 であるが, もし上部平板が固定されていなければ背 流により移動することが推測できる.

本研究は背流により駆動するマイクロアクチュエータの開発 を目的とし，その基掕研究として平行平板間における背流の速度 分布の測定およひ背流による平板の移動実験を行った。

\section{2. 実験方法}

速度分布の測定には図 3 のような液晶セルを用いた. 2 枚のガ ラスの内壁面には透明電極膜 (ITO膜) と液晶配向膜（ポリイミ ト膜)を施してある. 液晶配向膜はセル中の液晶に任意のツイス ト角を与えるためのものある. セルギャップは 50um, 印加電玨 は $5 \mathrm{~V}$, ツイスト角は 00 である. 実験には 5CB 液晶 (4-cyano-4'-npentylbiphenyl)にトレーサとして直径 2.5um のポリスチレン微柆 子適量を混入したものを使用した。夷験江顕微鏡下で行い，映像 を動画としてコンピュータに取り込んだ後, 画像解析により微柆 子の移動量を求めた. 図 4 は時間 $t$ に対する微柆子の移動量 $d$ の 一例である. 図の勾配より微粒子の移動速度を算出できる.



Fig. 1 Generation of back flow

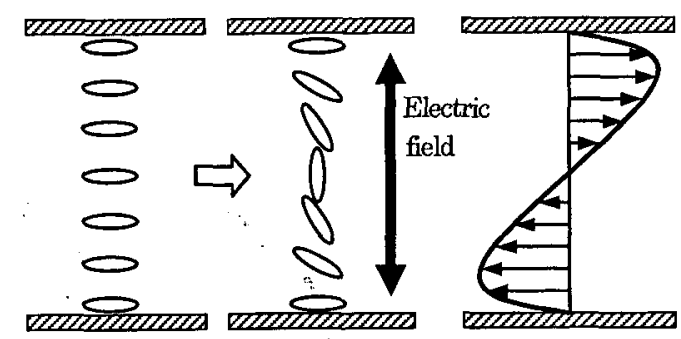

Fig. 2 Back-flow between parallel plates

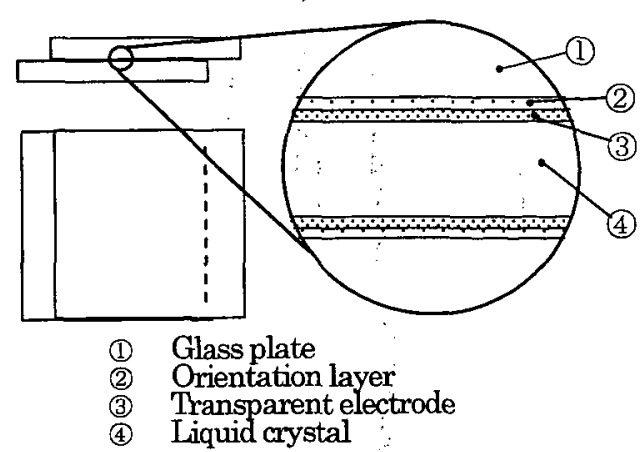

Fig. 3 Structure of an experimental cell 
図 5 は平板移動実験の概略である.上述の実験と同様に2 枚の ガラス平板には透明電極膜と配向膜を施してある.移動対象であ る上部平板は 1 辺 $10 \mathrm{~mm}$ の正方形，厚さ $0.2 \mathrm{~mm}$, 質量約 $0.05 \mathrm{~g}$ とし，下部平板は 1 辺 $20 \mathrm{~mm}$ の正方形とした，上下の平板はツ イスト角が 00 となるように組み合わせ，平板間隔を一定に保つ ためのスペーサとして直径 $300 \mu \mathrm{m}$ のポりスチレン微粒子を10個 程度散布した．また，上部平板と電源との接続は金線（電源側： 直径 $100 \mu \mathrm{m}$, 平板側 : 直径 $25 \mu \mathrm{m}$ ）を用いた点接触とした. この 状態で平板間に $5 \mathrm{CB}$ 液晶を充填し，さらに表面張力の影響を低 減するため上部平板全体を液晶で覆った. 平板間に印加した電圧 は10Vである. 電圧の印加は移動量の測定終了まで継䊦した.

上部平板の移動量およひ移動速度の測定は流速分布の測定と 同様，画像解析により行った.

\section{3. 実験結果および考察}

図6は微柆子の最大速度のセル厚方向分布を示す、図の縦軸は セル厚方向の位置 $y$ をセル厚 $H$ で除した無次元座標で, セルの

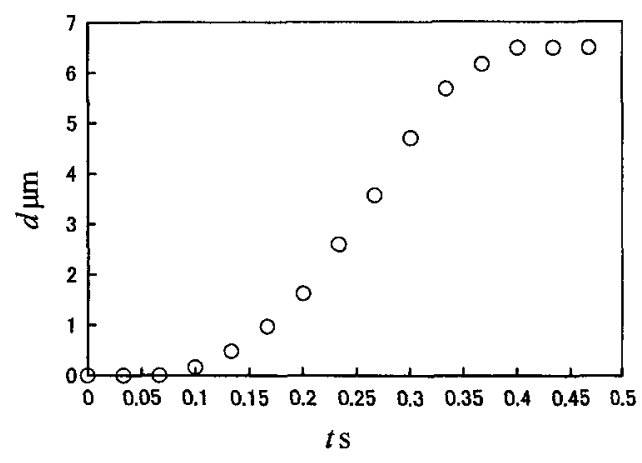

Fig. 4 Moved distance of a particle

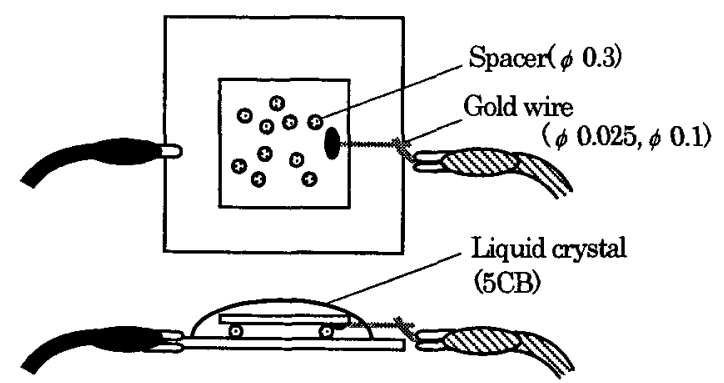

Fig. 5 Experimental setup



Fig. 6 Comparison of velocity profiles
中央面を 0 としている. 横䌷は微粒子の最大速度 $u_{\max }$ である. $y$ 方向の各位置で5〜7回の測定を行い，その平均值をエラーバー と共にプロットしてある. なお，図中の曲線は数値計算より得ら れた分布である. 図よりセルの中央部に対して $u_{\text {max }}$ の符号が反 転して扔り，セルの上部之下部で逆方向の流動が発生しているこ とがわかる. 数值計算の結果も同様の傾向走示しており，両者は 定性的に良く一致していると言える.

背流による平板の移動を試みた結果，実際に平板を移動させる ことに成功した. 図 7，8は上部平板の初期位置からの移動量お よひ移動速度を約 0.03 秒ごとにプロットしたグラフである. 図 の横軸は電土を印加してからら経過時間 $t$, 縦軸はそれぞれ平板 の移動量 $d$ およひ移動速度 $v$ である. 上部平板は $=1 \mathrm{~s}$ 付近から 緩や力䔟動を始如， $=1.5 \mathrm{~s}$ 頃から急激に加速しながら移動し， $t=1.83 \mathrm{~s}$ において最大速度約 $179 \mu \mathrm{m} / \mathrm{s}$ をとった後，およとた $2 \mathrm{~s}$ 静止に至る. 最終的な移動量注約 $38 \mu \mathrm{m}$ である.

\section{謝 辞}

本実験に用いたポリスチレン微垃子と配向膜材料を提供して頂 いた積水化学工業株式会社と JSR 株式会社に深謝の意を表す。

\section{参考文献}

1) Chandrasekhar, S. , 液晶の物理学, (1995), 188, 吉岡畫店.

2）小笠原 - 他 2 名，日本機械学会中国四国支部第 40 期講演 論文集，NO. 025-1，(2002)， 273.

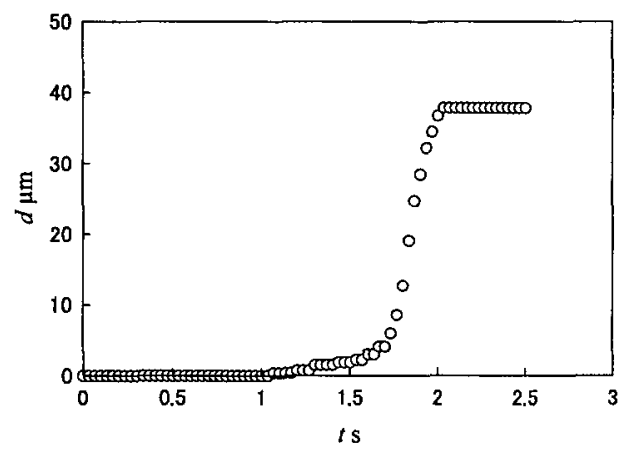

Fig. 7 Moved distance of the upper plate



Fig. 8 Velocity of the upper plate 